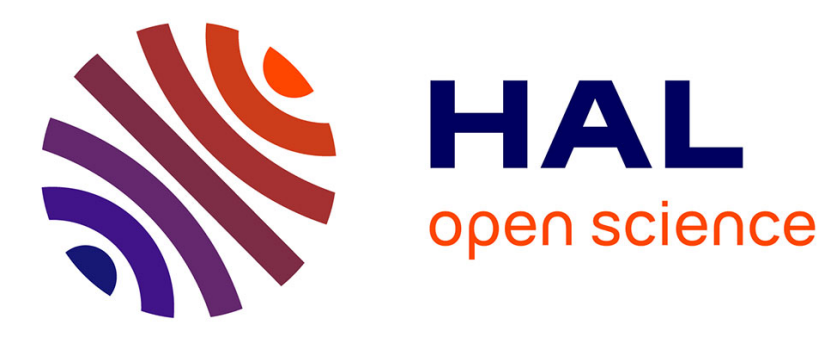

\title{
New ionic half-metallocenes of early lanthanides
}

Marc Visseaux, Philippe Zinck, Michael Terrier, André Mortreux, Pascal

Roussel

\section{To cite this version:}

Marc Visseaux, Philippe Zinck, Michael Terrier, André Mortreux, Pascal Roussel. New ionic half-metallocenes of early lanthanides. Journal of Alloys and Compounds, 2008, 451, pp.352. 10.1016/j.jallcom.2007.04.140 . hal-00264451

\section{HAL Id: hal-00264451 \\ https://hal.science/hal-00264451}

Submitted on 17 Mar 2008

HAL is a multi-disciplinary open access archive for the deposit and dissemination of scientific research documents, whether they are published or not. The documents may come from teaching and research institutions in France or abroad, or from public or private research centers.
L'archive ouverte pluridisciplinaire HAL, est destinée au dépôt et à la diffusion de documents scientifiques de niveau recherche, publiés ou non, émanant des établissements d'enseignement et de recherche français ou étrangers, des laboratoires publics ou privés. 


\title{
NEW IONIC HALF-METALLOCENES OF EARLY LANTHANIDES
}

(presented at the $6^{\text {th }}$ International Conference on f-elements, 4-9 ${ }^{\text {th }}$ September 2006, Wroctaw, Poland)

M. Visseaux, * P. Zinck, M. Terrier, A. Mortreux, P. Roussel

Unité de Catalyse et Chimie du Solide, UMR CNRS 8181. Ecole Nationale Supérieure de Chimie de Lille, Bât. C7, Cité Scientifique, 59652 Villeneuve d'Ascq cedex, France. Fax: (+33) (0)320436585

E-mail: marc.visseaux@ensc-lille.fr

\begin{abstract}
:
We present in this study a new and one-step method allowing the preparation of an unprecedented family of stable half-lanthanidocenes. X Ray analysis shows that the isolated compounds all display the same ionic $\mathrm{Ln}-\mathrm{Mg}$ bimetallic structure consisting of two anionic $\left(\mathrm{Cp}^{\mathrm{R}}\right) \mathrm{Ln}\left(\mathrm{BH}_{4}\right)_{3}$ species and one cationic $\mathrm{Mg}(\mathrm{THF})_{6}\left(\mathrm{Cp}^{\mathrm{R}}=\mathrm{C}_{5} \mathrm{Me}_{5}, \mathrm{Ln}=\right.$ $\mathrm{Nd}, \mathbf{1 a}, \mathrm{Ln}=\mathrm{La}, \mathbf{1} \mathbf{b} ; \mathrm{Cp}^{\mathrm{R}}=\mathrm{C}_{5} \mathrm{H}_{5}, \mathrm{Ln}=\mathrm{Nd}, \mathbf{2 a} ; \mathrm{Cp}^{\mathrm{R}}=\mathrm{C}_{5} \mathrm{H}_{2} \mathrm{Ph}_{3}, \mathrm{Ln}=\mathrm{Nd}$, 3a). Such complexes display high stability with respect to disproportionation in solution. Combined with dialkylmagnesium, neodymium complexes provide powerful catalysts for stereospecific isoprene polymerisation.
\end{abstract}

Keywords: polymers, elastomers, and plastics (A) • chemical synthesis (B) • catalysis (B) • crystal structure (C) • X Ray diffraction (D) 


\section{Introduction:}

Monocyclopentadienyl compounds of the rare earths represent a family of complexes that interest for catalysis has spectacularly increased since very recently $[1,2]$. The field of polymerisation is particularly most concerned, with the elaboration of unique controlled structure specialty polymeric materials $[3,4]$. However, the potential of such compounds - also called half-sandwiches or half-metallocenes - in catalysis is still little explored compared to metallocenes, mainly because their synthesis remains a challenge [5], due to the occurrence of comproportionation reactions [6, 7]. This has been observed in particular in the early series, even in the presence of one bulky cyclopentadienyl ligand [8, 9]. Thus, the half-lanthanidocenes chemistry remains mainly limited to the smaller elements $[6,10]$.

Recently however, taking advantage of the modularity of hapticity of the $\mathrm{BH}_{4}$ group, several monocyclopentadienyl complexes could be isolated by ionic metathesis (Scheme 1) [11-13].

(here scheme 1)

The more sophisticated $\sigma$-bond metathesis requires highly reactive homoleptic $\mathrm{LnR}_{3}$ precursors $(\mathrm{R}=$ alkyl [6, 14], allyl [15], phenyl [16], or amido group [17]), but this method advantageously allows the formation of the expected product in one step, with a minimal experimental work-up, as the formation of inorganic salts is avoided. However, heating may be necessary to achieve the metathesis reaction, and the possible formation of hazardous by-products requires extreme attention [18]. Furthermore, ligand scrambling may be not completely excluded using this strategy $[5,16]$. 
In the present paper, we propose an alternative method for the preparation of halfsandwiches of lanthanides in high yield, which conjugates the advantages of $\sigma$-bond metathesis, and the use of standard starting materials, the trisborohydrides $\mathrm{Ln}\left(\mathrm{BH}_{4}\right)_{3}(\mathrm{THF})_{3}$. Isolated complexes all exhibit the general ionic formula $\left[\left(\mathrm{Cp}^{\mathrm{R}}\right) \operatorname{Ln}\left(\mathrm{BH}_{4}\right)_{3}\right]_{2}\left[\mathrm{Mg}(\mathrm{THF})_{6}\right]\left(\mathrm{Cp}^{\mathrm{R}}\right.$ is a cyclopentadienyl ligand $)$. Polymerisation experiments show that all complexes are efficient precatalysts for isoprene polymerisation, affording highly trans-regular polymer in a controlled and living manner.

\section{Synthesis of ionic complexes}

\section{General scheme}

$\mathrm{Ln}\left(\mathrm{BH}_{4}\right)_{3}(\mathrm{THF})_{3}$ are common, easy to handle, and stable lanthanide compounds [19]. We first expected that they could be valuable starting materials for $\sigma$-bond metathesis since the [Ln]- $\mathrm{BH}_{4}$ moiety is known to display the chemical behavior of an hydride in some cases [20]. However, we observed by ${ }^{1} \mathrm{H}$ NMR that no reaction occurred between $\mathrm{C}_{5} \mathrm{Me}_{5} \mathrm{H}$ and $\mathrm{Nd}\left(\mathrm{BH}_{4}\right)_{3}(\mathrm{THF})_{3}$ even after a prolonged period. On the other hand, when the same reaction was carried out in the presence of one half-equivalent of BEM ( $n$ butylethylmagnesium $n \mathrm{BuEtMg}$ ) at room temperature, a quantitative reaction took place within a few minutes at room temperature. Repeating the same at the bulk scale, we could isolate a light blue crystalline solid in high yield (ca $80 \%$ ). According to ${ }^{1} \mathrm{H}$ NMR the new compound consisted of one $\mathrm{C}_{5} \mathrm{Me}_{5}$ ligand for $3 \mathrm{BH}_{4}$ groups (scheme 2). X-ray structure determination allowed to establish $\left[\left(\mathrm{C}_{5} \mathrm{Me}_{5}\right) \mathrm{Nd}\left(\mathrm{BH}_{4}\right)_{3}\right]_{2}\left[\mathrm{Mg}(\mathrm{THF})_{6}\right]$ (1a) as molecular formula for the isolated complex [21]. The similar procedure was successfully followed again with cyclopentadiene $\mathrm{C}_{5} \mathrm{H}_{5}$, and with 
triphenylcyclopentadiene $1,2,4-\mathrm{Ph}_{3} \mathrm{C}_{5} \mathrm{H}_{3}$, giving rise to the formation of $\left[\left(\mathrm{C}_{5} \mathrm{H}_{5}\right) \mathrm{Nd}\left(\mathrm{BH}_{4}\right)_{3}\right]_{2}\left[\mathrm{Mg}(\mathrm{THF})_{6}\right] \quad$ (2a) and $\left[\left(\mathrm{C}_{5} \mathrm{H}_{2} \mathrm{Ph}_{3}\right) \mathrm{Nd}\left(\mathrm{BH}_{4}\right)_{3}\right]_{2}\left[\mathrm{Mg}(\mathrm{THF})_{6}\right] \quad$ (3a), respectively. $\left[\left(\mathrm{C}_{5} \mathrm{Me}_{5}\right) \mathrm{La}\left(\mathrm{BH}_{4}\right)_{3}\right]_{2}\left[\mathrm{Mg}(\mathrm{THF})_{6}\right]$ (1b) was obtained as same from $\mathrm{La}\left(\mathrm{BH}_{4}\right)_{3}(\mathrm{THF})_{3}[22]$.

It must be emphasized that this unprecedented synthetic method, that we call the "borohydride route", requires very mild experimental conditions, and ordinary lanthanides precursors.

(here scheme 2)

\section{Mechanistic aspects}

The synthetic strategy employed was deduced from our ongoing studies on polymerisation with borohydrido compounds of lanthanides activated by alkylating reagents [23-26], which established unambiguously that [Ln]-R species were formed in the reaction medium. Two mechanistic pathways are possible, involving such [Ln]-R species which then react with $\mathrm{HCp}^{\mathrm{R}}$ through $\sigma$-bond metathesis (scheme 3 , i), or the reaction of $\mathrm{MgR}_{2}$ with $\mathrm{HCp}^{\mathrm{R}}$ first to form the corresponding magnesiocene, followed by the reaction with $\mathrm{Nd}\left(\mathrm{BH}_{4}\right)_{3}(\mathrm{THF})_{3}$ (scheme 3, ii).

(here scheme 3)

\section{Ray studies}


1a, 1b, 2a and 3a are all trinuclear ionic compounds comprising two anionic halfneodymocene trisborohydride $\left[\left(\mathrm{Cp}^{\mathrm{R}}\right) \mathrm{Nd}\left(\mathrm{BH}_{4}\right)_{3}\right]^{-}$moieties and one cationic hexa-THF magnesium $\left[\mathrm{Mg}(\mathrm{THF})_{6}\right]^{2+}$ adduct (Figs. 1-3) that alternate in the unit cell without particular cation - anion interaction [21, 22]. This ionic trinuclear structure is comparable to that of $\left[\mathrm{Mg}(\mathrm{THF})_{6}\right]\left[\mathrm{Nd}(\text { allyl })_{4}\right]_{2}(2 \mathrm{THF})$, obtained by ionic metathesis, with discrete $\left[\mathrm{Mg}(\mathrm{THF})_{6}\right]^{2+}$ cation and allyl neodymate anions [27].

(here Figures 1, 2, 3)

The molecular structures of complexes $\mathbf{1 a}, \mathbf{1 b}, \mathbf{2 a}$, and 3a exhibit very similar structural features:

- the $\left[\left(\mathrm{Cp}^{\mathrm{R}}\right) \mathrm{Nd}\left(\mathrm{BH}_{4}\right)_{3}\right]^{-}$anions have a pseudo tetrahedral tri-legged piano-stool geometry.

- The Mg cation exhibits the octahedral geometry with oxygen atoms of THF molecules.

- $\quad$ hydrogens belonging to borohydride groups could be located for 1a, 2a, and 3a. The geometric parameters (B-H, Ln-H distances, and B-H-Ln angles) are typical of monomeric borohydrido complexes bearing a tridentate $\mathrm{Ln}-\left(\eta^{3}-\mathrm{H}\right)_{3} \mathrm{~B}-\mathrm{H}$ terminal group [25, 28, 29]. In the case of $\mathbf{1 b}, \mathrm{B}-\mathrm{La}-\mathrm{B}$ angles and La-B distances are close (albeit slightly higher, due to the larger La vs. Nd) to these found in the Nd complexes, and thus in accordance with the same mode of bonding.

- In the case of $\mathbf{1 a}$ and $\mathbf{3 a}$, one of the $\mathrm{BH}_{4}$ ligand is distorted with one shorter $\mathrm{Nd}$ $\left(\mu_{2}-\mathrm{H}\right)$ distance. 
In all these complexes, the absence of coordinated THF to the lanthanide atom points out the higher affinity of the lanthanide towards ionic ligands.

\section{Stability of early half-lanthanidocenes}

As far as we know, a borohydride anion $\left[\left(\mathrm{Cp}^{\mathrm{R}}\right) \mathrm{Ln}\left(\mathrm{BH}_{4}\right)_{3}\right]^{-}$was observed just at once, in the ionic complex $\left\{\left[\mathrm{Sm}\left(\mathrm{BH}_{4}\right)_{2}(\mathrm{THF})_{\mathrm{n}}\right]^{+}\left[\left(\mathrm{C}_{5} \mathrm{Me}_{4}{ }^{\mathrm{n}} \mathrm{Pr}\right) \mathrm{Sm}\left(\mathrm{BH}_{4}\right)_{3}\right]^{-}\right\}$. This compound was obtained from the reaction of $\mathrm{Sm}\left(\mathrm{BH}_{4}\right)_{3}(\mathrm{THF})_{3}$ with a half equivalent of $\mathrm{K}\left(\mathrm{C}_{5} \mathrm{Me}_{4}{ }^{\mathrm{n}} \mathrm{Pr}\right)$ (Equation 1) [30] and crystals were isolated with $\mathrm{n}=5$ THF per metal.

\section{(here Equation 1)}

Monocyclopentadienyl of the larger lanthanides (from La to Sm) are known to easily undergo ligands redistribution reactions. Another possible evolution of such complexes is clustering, affording generally hexameric structures (scheme 4) [12].

(here Scheme 4)

With the aim to compare the stability of the anionic $\left[\left(\mathrm{C}_{5} \mathrm{Me}_{5}\right) \mathrm{Nd}\left(\mathrm{BH}_{4}\right)_{3}\right]^{-}$versus the neutral $\left(\mathrm{C}_{5} \mathrm{Me}_{5}\right) \mathrm{Nd}\left(\mathrm{BH}_{4}\right)_{2}(\mathrm{THF})_{2}$, a sample of each complex in $\mathrm{C}_{6} \mathrm{D}_{6}$ was kept $20 \mathrm{~h}$ at 75 ${ }^{\circ} \mathrm{C}$ in an NMR tube. We observed that the solution of 1a prepared in our one pot procedure remained unchanged after that period, whereas blue crystals had formed from the solution of $\left(\mathrm{C}_{5} \mathrm{Me}_{5}\right) \mathrm{Nd}\left(\mathrm{BH}_{4}\right)_{2}(\mathrm{THF})_{2}$. X Ray analysis showed that the crystals corresponded to the hexamer $\left[\left(\mathrm{C}_{5} \mathrm{Me}_{5}\right) \mathrm{Nd}\left(\mathrm{BH}_{4}\right)_{2}\right]_{6}[31]$. 
The isolation of 2a and 3a was more surprising. In the unsubstituted $\mathrm{C}_{5} \mathrm{H}_{5}$ series, halflanthanidocenes of the larger lanthanides are exceptional $[6,10]$, whereas 3a is the first structurally characterized lanthanide complex featuring the bulky but electronwithdrawing $\mathrm{C}_{5} \mathrm{H}_{2} \mathrm{Ph}_{3}$ ligand [33]. It is worth to be noted that the corresponding neutral half-sandwich could not be isolated pure by ionic metathesis [24].

Thus, $\left[\left(\mathrm{Cp}^{\mathrm{R}}\right) \mathrm{LnX}_{3}\right]^{-}$appears as a stable molecular entity in the borohydride series, with respect to comproportionation or clustering.

\section{Isoprene Polymerisation}

We showed recently that combining a lanthanide borohydride with a dialkylmagnesium is a valuable strategy to prepare, in situ, efficient lanthanide-based catalysts that are also highly trans-stereospecific towards isoprene polymerization [4, 25]. Similarly, the addition of a stoichiometric amount of BEM (1:1) to ionic neodymium complexes 1a, 2a, and 3a gave rise in each case to a very valuable initiator (Table 1, runs 1-3). All these catalysts afford a highly trans-regular polymer ( $>95 \%$ according to NMR, see Figure 4) [32], as well as good control over the macromolecular data (fine agreement between calculated and measured molecular weights, and narrow polydispersities), typical of a single-site process. Besides, the catalytic behaviour of 1a / 1BEM system, the most active, was found fully comparable to that one obtained from the neutral $\left(\mathrm{C}_{5} \mathrm{Me}_{5}\right) \mathrm{Nd}\left(\mathrm{BH}_{4}\right)_{2}(\mathrm{THF})_{2}$ (run 1 vs. 4). Thus, both catalysts most probably involve the same half-sandwich catalytic species (for a discussion on this question, see ref 4). It is confirmed that the more bulky the $\mathrm{Cp}^{\mathrm{R}}$ ligand, the higher the trans-stereospecificity [4], whereas the activity of the catalyst decreases with the electronic richness of the cyclopentadienyl ligand, as already observed [33]. 
(here Table 1)

To conclude, the "borohydride route" is an elegant alternative for the preparation of half-sandwiches of early lanthanides, enabling a one pot and high yield synthesis of such complexes. Thanks to this method, it is possible to prepare very easily unprecedented lanthanide-based catalysts. It will be shown in a forthcoming paper that this approach also allows the formation of mixed magnesium lanthanidocene complexes.

\section{References}

[1] See for example the special issue of Chem. Rev. 102 (2002) 6.

[2] D. Cui, O. Tardif, Z. Hou, J. Am. Chem. Soc. 126 (2004) 1312.

[3] Z. Hou, Y. Luo, X. Li, J. Organomet. Chem. 691 (2006) 3114.

[4] F. Bonnet, M. Visseaux, A. Pereira, D. Barbier-Baudry, Macromolecules 38 (2005) 3162.

[5] R. Anwander, M. G. Klimpel, H. M. Dietrich, D. J. Shorokov, W. Scherer, J. Chem. Soc. Chem. Commun. (2003) 1008.

[6] S. Arndt, J. Okuda, Chem. Rev. 102 (2002) 1953.

[7] R. Poli, Chem. Rev. 91 (1991) 509.

[8] H. J. Heeres, A. Meetsma, J. H. Teuben, R. D. Rogers, Organometallics 8 (1989) 2637.

[9] H. M. Dietrich, G. Raudaschl-Sieber, R. Anwander, Angew. Chem. Int. Ed. 44 (2005) 5303. 
[10] H. Schumann, J. Meese-Marktscheffel, L. Esser, Chem. Rev. 95 (1995) 865.

[11] D. Barbier-Baudry, O. Blacque, A. Hafid, A. Nyassi, H. Sitzmann, M. Visseaux, Eur. J. Inorg. Chem. (2000) 2333.

[12] F. Bonnet, M. Visseaux, A. Hafid, D. Barbier-Baudry, E. Vigier, M. M. Kubicki, Inorg. Chem. 43 (2004) 3682.

[13] S. Cendrowski-Guillaume, G. Le Gland, M. Nierlich, M. Ephritikhine, Organometallics 19 (2000) 5654.

[14] S. Bambirra, M. W. Bouwkamp, A. Meetsma, B. Hessen, J. Am. Chem. Soc. $126(2004) 9182$.

[15] R. Taube, S. Maiwald, J. Sieler, J. Organomet. Chem. 513 (1996) 37.

[16] M. Booij, N. H. Kiers, H. J. Heeres, J. H. Teuben, J. Organomet. Chem. 365 (1989) 79.

[17] R. Anwander, Top. Organomet. Chem. 2 (1999) 1.

[18] H. M. Dietrich, C. Zapilko, E. Herdtweck, R. Anwander, Organometallics 24 (2005) 5767.

[19] U. Mirsaidov, I. B. Shaimuradov, M. Khikmatov, Russ. J. Inorg. Chem. 5 (1986) 753.

[20] S. M. Guillaume, M. Schappacher, A. Soum, Macromolecules 36 (2003) 54.

[21] M. Visseaux, M. Terrier, A. Mortreux, P. Roussel, submitted to J. Am. Chem. Soc.

[22] Syntheses: [Cp* $\left.\mathrm{La}\left(\mathrm{BH}_{4}\right)_{3}\right]_{2} \mathrm{Mg}(\mathrm{THF})_{6}, \mathbf{1 b}: 275 \mathrm{mg}(0.5 \mathrm{mmol})$ of BEM (20\% solution in hexanes) diluted in $10 \mathrm{~mL}$ of toluene were added dropwise, at room temperature, to a solution of $\mathrm{La}\left(\mathrm{BH}_{4}\right)_{3}(\mathrm{THF})_{3}(400.0 \mathrm{mg}, 1 \mathrm{mmol})$ and $\mathrm{Cp} * \mathrm{H}(136 \mathrm{mg}$, $1 \mathrm{mmol})$ in toluene $(20 \mathrm{~mL})$. The mixture turned from white to light yellow 
immediately. After $1 \mathrm{~h}$ of stirring at room temperature, the solvents were evaporated to dryness. $10 \mathrm{~mL}$ of THF were added by vacuum transfer into the flask, leading to a limpid uncoloured solution. The THF was evaporated to give an off-white sticky compound, that was redissolved in toluene $(20 \mathrm{~mL})$ through the same vacuum transfer process. After a filtration to eliminate insoluble residues present in small quantities (ca $30 \mathrm{mg}$ ), this solution was slowly concentrated, leading to a crop of well-formed white crystals (407 mg; $0.37 \mathrm{mmol}, 74.4 \%$ ). Anal. Calc. $\mathrm{C}_{44} \mathrm{H}_{102} \mathrm{~B}_{6} \mathrm{O}_{6} \mathrm{La}_{2} \mathrm{Mg}$ : C, 48.26; H, 9.32. Found: $\mathrm{C}, 47.94 ; \mathrm{H}, 9.23 .{ }^{1} \mathrm{H} \mathrm{NMR}\left(\mathrm{C}_{6} \mathrm{D}_{6}\right) \delta: 1.1\left(\mathrm{br}, 12 \mathrm{H}, \mathrm{BH}_{4}, \mathrm{v}_{1 / 2}=100 \mathrm{~Hz}\right)$, $2.36(\mathrm{~s}, \quad \mathrm{MeCp}, \quad 15 \mathrm{H}), \quad 3.69 \quad(\mathrm{~s}, \quad \mathrm{THF}, \quad 12 \mathrm{H}), \quad 1.27 \quad(\mathrm{~s}, \quad \mathrm{THF}, \quad 12 \mathrm{H})$. $\left[\mathrm{CpNd}\left(\mathrm{BH}_{4}\right)_{3}\right]_{2} \mathrm{Mg}(\mathrm{THF})_{6}, 2 \mathrm{a}: 235 \mathrm{mg}(0.43 \mathrm{mmol})$ of BEM (20\% solution in hexanes) diluted in $10 \mathrm{~mL}$ of toluene were added dropwise, at room temperature, to a solution of $\mathrm{Nd}\left(\mathrm{BH}_{4}\right)_{3}(\mathrm{THF})_{3}(405.0 \mathrm{mg}, 1.0 \mathrm{mmol})$ and freshly cracked $\mathrm{CpH}(65 \mathrm{mg}, 1.0 \mathrm{mmol})$ in toluene $(20 \mathrm{~mL})$. The mixture turned from light purple to blue immediately. Progressively, a pale blue precipitate formed. After $1 \mathrm{~h}$ of stirring at room temperature, the solvents were evaporated off, and THF $(15 \mathrm{~mL})$ was distilled by vacuum transfer into the flask, leading to a limpid blue solution. The THF was evaporated to give a sticky blue compound, that was redissolved in toluene $(20 \mathrm{~mL})$ through the same vacuum transfer process. The toluene solution was filtrated to eliminate small quantities of insoluble residues, then slowly concentrated within 4 hours to ca. $2 \mathrm{~mL}$. A first crop (30 mg) of light blue crystals, suitable for X Ray structure analysis, could be collected. A second crop was obtained after standing 24 hours at room temperature; it was washed successively with cold toluene and cold pentane, and dried under vacuum at room temperature $(214 \mathrm{mg})$. From the mother liquor, $54 \mathrm{mg}$ of a blue crystalline solid could be finally obtained after concentration, decantation, and drying. Total yield: $298 \mathrm{mg}$; 
$71.9 \%$ (with respect to $\mathrm{Mg}$ ). Anal. Calc. $\mathrm{C}_{34} \mathrm{H}_{82} \mathrm{~B}_{6} \mathrm{O}_{6} \mathrm{Nd}_{2} \mathrm{Mg}$ : C, 42.33; H, 8.57. Found: C, 42.52; H, 8.37. ${ }^{1} \mathrm{H}$ NMR $\left(\mathrm{C}_{6} \mathrm{D}_{6}\right) \delta: 65$ (v. br, $\left.12 \mathrm{H}, \mathrm{BH}_{4}, \mathrm{v}_{1 / 2}>2000 \mathrm{~Hz}\right), 0.93$ (THF), 0.29 (THF), $-2.65(\mathrm{~s}, \mathrm{Cp}, 15 \mathrm{H}) .\left[\mathrm{C}_{5} \mathrm{H}_{2} \mathrm{Ph}_{3} \mathrm{Nd}\left(\mathrm{BH}_{4}\right)_{3}\right]_{2} \mathrm{Mg}(\mathrm{THF})_{6}$, 3a: same procedure as for 2a, from $275 \mathrm{mg}(0.5 \mathrm{mmol})$ of BEM (20\% hexane solution), $405 \mathrm{mg}(1 \mathrm{mmol}) \mathrm{of}$ $\mathrm{Nd}\left(\mathrm{BH}_{4}\right)_{3}(\mathrm{THF})_{3}$, and $294 \mathrm{mg}(1 \mathrm{mmol})$ of $\mathrm{HC}_{5} \mathrm{H}_{2} \mathrm{Ph}_{3}$. Suitable X Ray crystals could be collected from a toluene solution slowly evaporated inside the glove box. Total yield: $360 \mathrm{mg} ; 53.5$ \%. Anal. Calc. $\mathrm{C}_{70} \mathrm{H}_{106} \mathrm{~B}_{6} \mathrm{O}_{6} \mathrm{Nd}_{2} \mathrm{Mg}$ : C, 59.13; H, 7.52. Found: $\mathrm{C}, 59.39$; H, 7.75 .

X Ray structures analyses: Compound $\mathbf{1 b}\left(\mathrm{C}_{88} \mathrm{H}_{204} \mathrm{~B}_{12} \mathrm{La}_{4} \mathrm{Mg}_{2} \mathrm{O}_{12}\right)$ crystallizes in the monoclinic space group $\mathrm{P} 21_{1}$ with $\mathrm{a}=11.077(3), \mathrm{b}=30.239(8), \mathrm{c}=17.680(5) \AA, \beta=$ 106.257(4) ${ }^{\circ}, V=5685(3) \AA^{3}$, and $\rho=1.278 \mathrm{gcm}^{-3}$ for $Z=2$. Data were collected at 100 $\mathrm{K}$ on a Bruker Smart-CCD $1 \mathrm{~K}$ system. The structure was solved by direct methods using SHELXS-97 package (Sheldrick, 1990), and least-square refinement of the model based on 18293 reflections $(\mathrm{I}>2.0 \sigma(\mathrm{I}))$ converged to a final $\mathrm{R}=6.29 \%\left(\mathrm{wR}_{2}=15.51 \%\right)$. Except $\mathrm{H}$ pertaining to $\mathrm{BH}_{4}$ groups, all hydrogen atoms were placed in calculated positions. Others were located in difference Fourier maps and refined with isotropic thermal parameters. Compound 2a $\left(\mathrm{C}_{34} \mathrm{H}_{82} \mathrm{~B}_{6} \mathrm{MgNd}_{2} \mathrm{O}_{6}\right)$ crystallizes in the triclinic space group P-1 (2) with $\mathrm{a}=10.016(9), \mathrm{b}=10.178(9), \mathrm{c}=12.859(12) \AA, \alpha=$ $110.335(14)^{\circ}, \beta=94.702(14)^{\circ}, \gamma=96.491(14)^{\circ}, \mathrm{V}=1211.0(19) \AA^{3}$, and $\rho=1.323$ $\mathrm{gcm}^{-3}$ for $\mathrm{Z}=1$. Data were collected at $100 \mathrm{~K}$ on a Bruker Smart-CCD $1 \mathrm{~K}$ system. The structure was solved by direct methods using SHELXS-97 package (Sheldrick, 1990), and least-square refinement of the model based on 4698 reflections (I>2.0 $\sigma(\mathrm{I}))$ converged to a final $\mathrm{R}=2.75 \%\left(\mathrm{wR}_{2}=6.62 \%\right)$. Except $\mathrm{H}$ pertaining to $\mathrm{BH}_{4}$ groups, all hydrogen atoms were placed in calculated positions. Others were located in difference 
Fourier maps and refined with isotropic thermal parameters. Compound 3a $\left(\mathrm{C}_{35} \mathrm{H}_{53} \mathrm{~B}_{3} \mathrm{NdMg}_{0.5} \mathrm{O}_{3}\right)$ crystallizes in the triclinic space group $\mathrm{P}-1$ (2) with $\mathrm{a}=$ 10.051(5), $\mathrm{b}=10.839(5), \mathrm{c}=17.695(8) \AA, \alpha=74.629(7)^{\circ}, \beta=84.793(7)^{\circ}, \gamma=$ 74.315(7) ${ }^{\circ}, \mathrm{V}=1789.1(14) \AA^{3}$, and $\rho=1.491 \mathrm{gcm}^{-3}$ for $\mathrm{Z}=2$. Data were collected at $100 \mathrm{~K}$ on a Bruker Smart-CCD 1K system. The structure was solved by direct methods using SHELXS-97 package (Sheldrick, 1990), and least-square refinement of the model based on 5600 reflections $(\mathrm{I}>2.0 \sigma(\mathrm{I}))$ converged to a final $\mathrm{R}=6.03 \%\left(\mathrm{wR}_{2}=13.62 \%\right)$. Except $\mathrm{H}$ pertaining to $\mathrm{BH}_{4}$ groups, all hydrogen atoms were placed in calculated positions. Others were located in difference Fourier maps and refined with isotropic thermal parameters. CCDC-618594, CCDC-618595 and CCDC-618596 contains the supplementary crystallographic data corresponding to $\mathbf{1 b}, \mathbf{2 a}$, and $\mathbf{3 a}$, respectively. These data can be obtained free of charge via www.ccdc.cam.ac.uk/conts/retrieving.html (or from the Cambridge Crystallographic Data Centre, 12 Union Road, Cambridge CB21EZ, UK; fax: (+44) 1223-336- 033; or deposit@ccdc.cam.ac.uk.

[23] F. Bonnet, M. Visseaux, A. Pereira, F. Bouyer, D. Barbier-Baudry, Macromol. Rapid Commun. 25 (2004) 873.

[24] M. Visseaux, A. S. Madureira Bruno, F. Bouyer, D. Barbier-Baudry, Appl. Organometal. Chem. 20 (2006) 24.

[25] M. Visseaux, T. Chenal, A. Mortreux, P. Roussel, J. Organomet. Chem. 691 (2006) 86 .

[26] M. Visseaux, P. Zinck, A. Mortreux, Z. Anorg. All. Chem. (2006) in press.

[27] L. F. Sanchez-Barba, D. L. Hughes, S. M. Humphrey, M. Bochmann, Organometallics 24 (2005) 5329. 
[28] H. Schumann, M. R. Keitsch, S. H. Muhle, Acta Cryst. C56 (2000) 48.

[29] C. T. Qian, G. Zou, W. Nie, J. Sun, D. A. Lemenovski, M. V. Borzov, Polyhedron 19 (2000) 1955.

[30] F. Bonnet, M. Visseaux, A. Hafid, D. Barbier-Baudry, E. Vigier, M. M. Kubicki, submitted to Inorg. Chem. Commun. (2006).

[31] Unpublished results

[32] Stereospecificity was determined by both ${ }^{1} \mathrm{H}$ and ${ }^{13} \mathrm{C}$ NMR integrations. The average variation observed is of \pm 0.2 on the value of the percentage for several measurements of the same sample; \% of trans-stereospecificity results from $\%$ of $3,4-$ and cis-defects in polyisoprenes, calculated as follows from ${ }^{1} \mathrm{H}$ NMR integration: $(\delta$ ppm) 5.11 (a) ; 4.68 (b) ; 1.68 (c)

$$
\% \text { cis }=\frac{c / 3}{a+b / 2} \quad \% 3,4=\frac{b / 2}{a+b / 2} \quad \% \text { trans }=100-\% \text { cis }-\% 3,4
$$

The values found are corroborated by those calculated from ${ }^{13} \mathrm{C}$ NMR: $(\delta$ ppm) 16.4 (e) $; 18.9$ (f) ; 23.8 (g)

$$
\% \text { trans }=\frac{e}{e+f+g} \quad \% \text { cis }=\frac{f}{e+f+g} \quad \% 3,4=\frac{g}{e+f+g}
$$

[33] F. Bonnet, M. Visseaux, D. Barbier-Baudry, J. Organomet. Chem. 689 (2004) 264. 


$$
\begin{aligned}
\operatorname{Ln}\left(\mathrm{BH}_{4}\right)_{3}(\mathrm{THF})_{3}+\mathrm{K}\left(\mathrm{Cp}^{\mathrm{R}}\right) \longrightarrow & \left(\mathrm{Cp}^{\mathrm{R}}\right) \mathrm{Ln}\left(\mathrm{BH}_{4}\right)_{2}(\mathrm{THF})_{\mathrm{n}}+\mathrm{KBH}_{4} \\
& \mathrm{Cp}^{\mathrm{R}}=\mathrm{C}_{5} \mathrm{H}^{\mathrm{i}} \mathrm{Pr}_{4}, \mathrm{C}_{5} \mathrm{Me}_{4}{ }^{\mathrm{n}} \mathrm{Pr}_{1} \mathrm{C}_{5} \mathrm{Me}_{5} ; \\
& \mathrm{Ln}=\mathrm{Nd}, \mathrm{Sm}
\end{aligned}
$$

Scheme 1: synthesis of the monocyclopentadienyl borohydride complexes by ionic metathesis

$$
\begin{aligned}
\operatorname{Ln}\left(\mathrm{BH}_{4}\right)_{3}(\mathrm{THF})_{3}+\mathrm{HCp}^{\mathrm{R}}+0.5{ }^{\mathrm{n}} \mathrm{BuEtMg} \stackrel{\begin{array}{l}
\text { 1. toluene } \\
\text { 2. THF }
\end{array}}{\text { 3. toluene }} \longrightarrow \\
\end{aligned}
$$

Scheme 2. Synthesis of the ionic monocyclopentadienyllanthanide complexes by the "borohydride / alkyl route"

$$
\begin{gathered}
2\left(\mathrm{BH}_{4}\right)_{3} \mathrm{Nd}+\mathrm{MgR}_{2} \underset{\mathrm{i}}{\longrightarrow} 2\left(\mathrm{BH}_{4}\right)_{3} \mathrm{Nd}-\mathrm{R}^{-}+\mathrm{Mg}^{2+} \rightleftharpoons 2\left(\mathrm{BH}_{4}\right)_{3} \mathrm{Nd}-\mathrm{R}^{-}+\mathrm{Mg}^{2+} \\
\begin{array}{c}
2 \mathrm{RH} \\
{\left[\left(\mathrm{Cp}^{\mathrm{R}}\right) \mathrm{Nd}\left(\mathrm{BH}_{4}\right)_{3}\right]_{2}\left[\mathrm{Mg}(\mathrm{THF})_{6}{ }^{2+}\right]}
\end{array} \\
\uparrow_{2 \mathrm{HCp}^{\mathrm{R}}+\mathrm{MgR}_{2} \stackrel{\mathrm{ii}}{\longrightarrow} \mathrm{Nd}\left(\mathrm{BH}_{4}\right)_{3}}^{\longrightarrow} \mathrm{Mg}\left(\mathrm{Cp}^{\mathrm{R}}\right)_{2}+2 \mathrm{RH}
\end{gathered}
$$

Scheme 3. The possible mechanistic pathways of the «borohydride/ alkyl route » (THF omitted for clarity) 


$$
\left(\mathrm{C}_{5} \mathrm{Me}_{4}{ }^{\mathrm{n}} \operatorname{Pr}\right) \operatorname{Ln}\left(\mathrm{BH}_{4}\right)_{2}(\mathrm{THF})_{2} \stackrel{\mathrm{THF}}{\rightleftharpoons}\left[\left(\mathrm{C}_{5} \mathrm{Me}_{4}{ }^{\mathrm{n}} \operatorname{Pr}\right) \operatorname{Ln}\left(\mathrm{BH}_{4}\right)_{2}\right]_{6}
$$

Scheme 4

$\mathrm{Sm}\left(\mathrm{BH}_{4}\right)_{3}(\mathrm{THF})_{3}+1 / 2 \mathrm{KC}_{5} \mathrm{Me}_{4}{ }^{\mathrm{n}} \mathrm{Pr} \underset{\text { 1. toluene }}{2 . \mathrm{THF}} 1 / 2\left\{\left[\mathrm{Sm}\left(\mathrm{BH}_{4}\right)_{2}(\mathrm{THF})_{3}\right]^{+}\left[\left(\mathrm{C}_{5} \mathrm{Me}_{4}{ }^{\mathrm{n}} \mathrm{Pr}\right) \operatorname{Sm}\left(\mathrm{BH}_{4}\right)_{3}\right]^{-}\right\}$

Equation 1 


\section{FIGURES CAPTIONS}

Figure 1. One of the two entities of the asymmetric unit showing the molecular structure of $\left[\left(\mathrm{C}_{5} \mathrm{Me}_{5}\right) \mathrm{La}\left(\mathrm{BH}_{4}\right)_{3}\right]_{2}\left[\mathrm{Mg}(\mathrm{THF})_{6}\right]$ (1a). Hydrogen atoms are omitted for clarity. La2Mg2 7.363(4) Å, La2-B (average B4-B6) 2.70 Å, B-La2-B (average B4-B6) 105.1 ․

Figure 2. Molecular structure of $\left[\left(\mathrm{C}_{5} \mathrm{H}_{5}\right) \mathrm{Nd}\left(\mathrm{BH}_{4}\right)_{3}\right]_{2}\left[\mathrm{Mg}(\mathrm{THF})_{6}\right]$ (2a). Non- $\mathrm{BH}_{4}$ hydrogen atoms are omitted for clarity. Nd-Mg 7.225(4) $\AA$, Nd-B (average B1-B3) 2.61 $\AA$, B-Nd-B (average B1-B3) $104.6^{\circ}$.

Figure 3. Molecular structure of $\left[\left(\mathrm{C}_{5} \mathrm{H}_{2} \mathrm{Ph}_{3}\right) \mathrm{Nd}\left(\mathrm{BH}_{4}\right)_{3}\right]_{2}\left[\mathrm{Mg}(\mathrm{THF})_{6}\right]$ (3a). Non- $\mathrm{BH}_{4}$ hydrogen atoms are omitted for clarity. Nd-Mg 7.323(2) $\AA$, Nd-B (average B1-B3) 2.61 Å, B-Nd-B (average B1-B3) $104.3^{\circ}$.

Figure 4. (a) ${ }^{1} \mathrm{H}$ NMR spectrum of trans-polyisoprene from precatalyst $3 \mathbf{a}\left(\mathrm{CDCl}_{3}\right)$. 3,4-defects: $\delta=4.68$ ppm, $\mathrm{CH}$ signal; O 1,4-cis defects: $\delta=1.68 \mathrm{ppm}, \mathrm{CH}_{3}$ signal. (b) ${ }^{13} \mathrm{C}\left\{{ }^{1} \mathrm{H}\right\}$ NMR spectrum of trans-polyisoprene from 3a $\left(\mathrm{CDCl}_{3}\right) . * 3$,4-defects: Me signal, $\delta=23.8$ ppm; O 1,4-cis defects: $\delta=18.9$ ppm, Me signal 


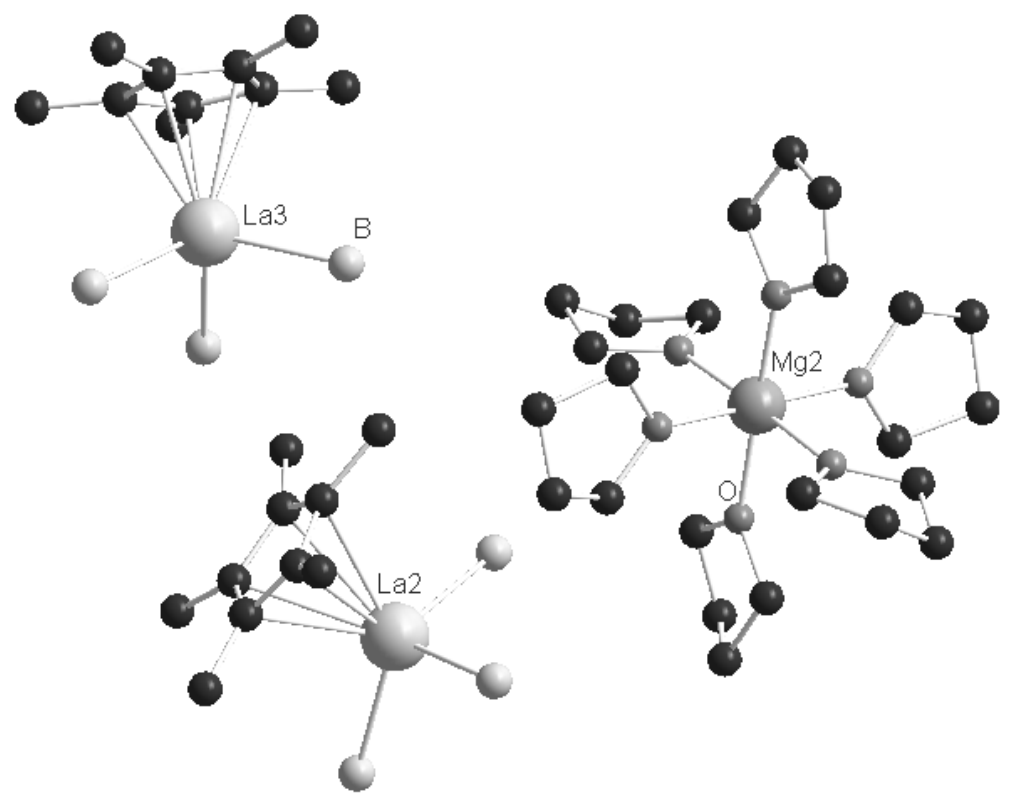

Figure 1 


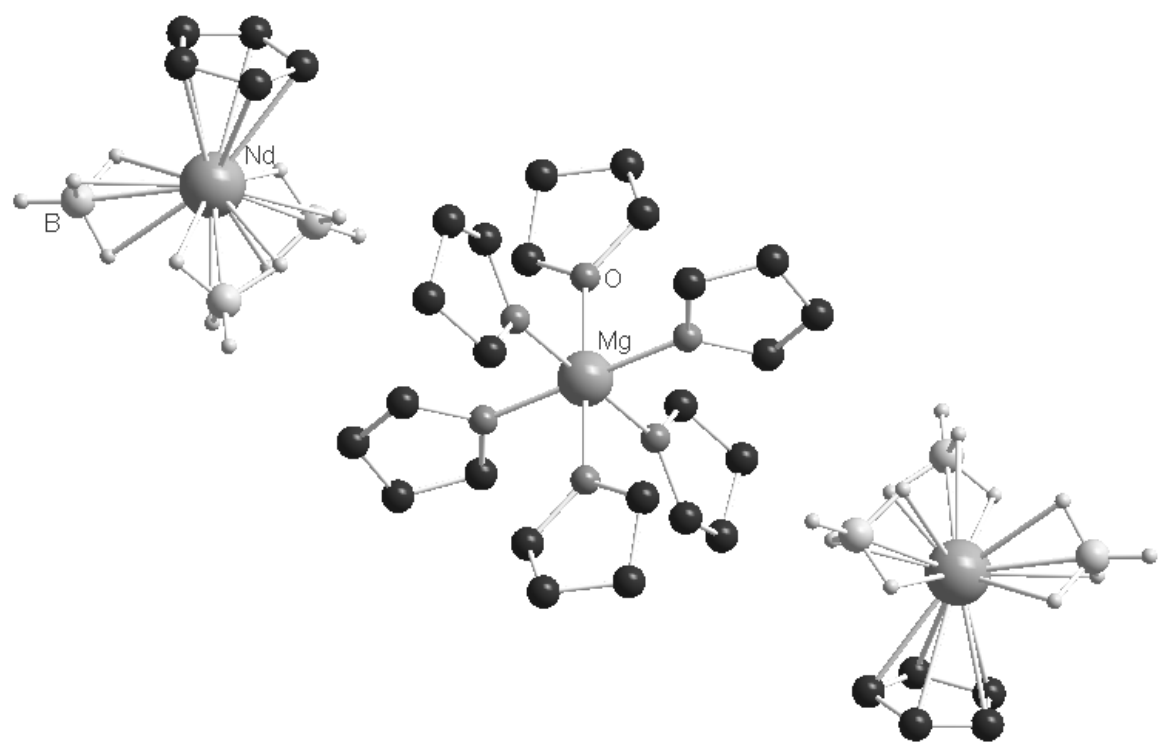

Figure 2 


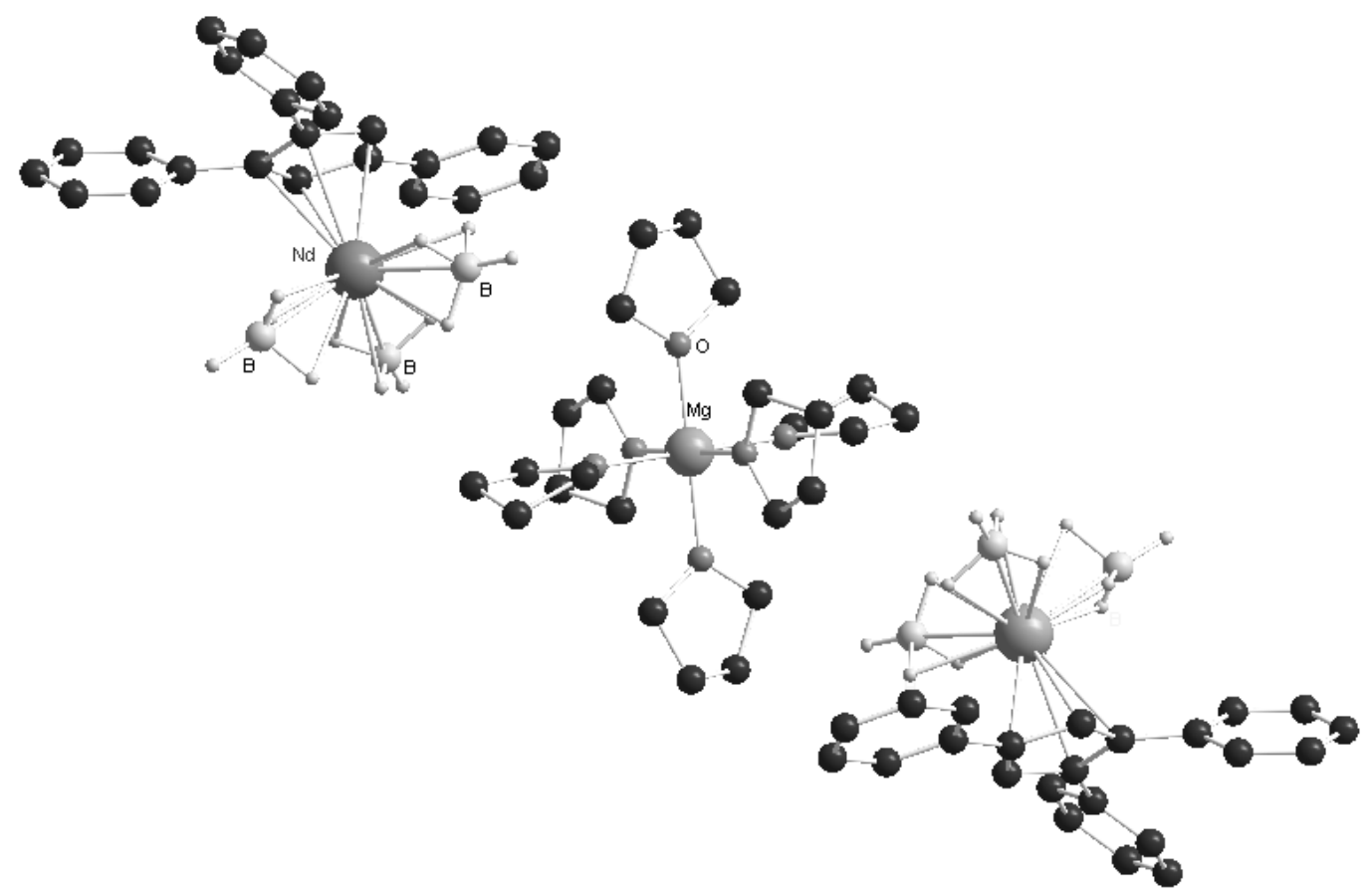

Figure 3 


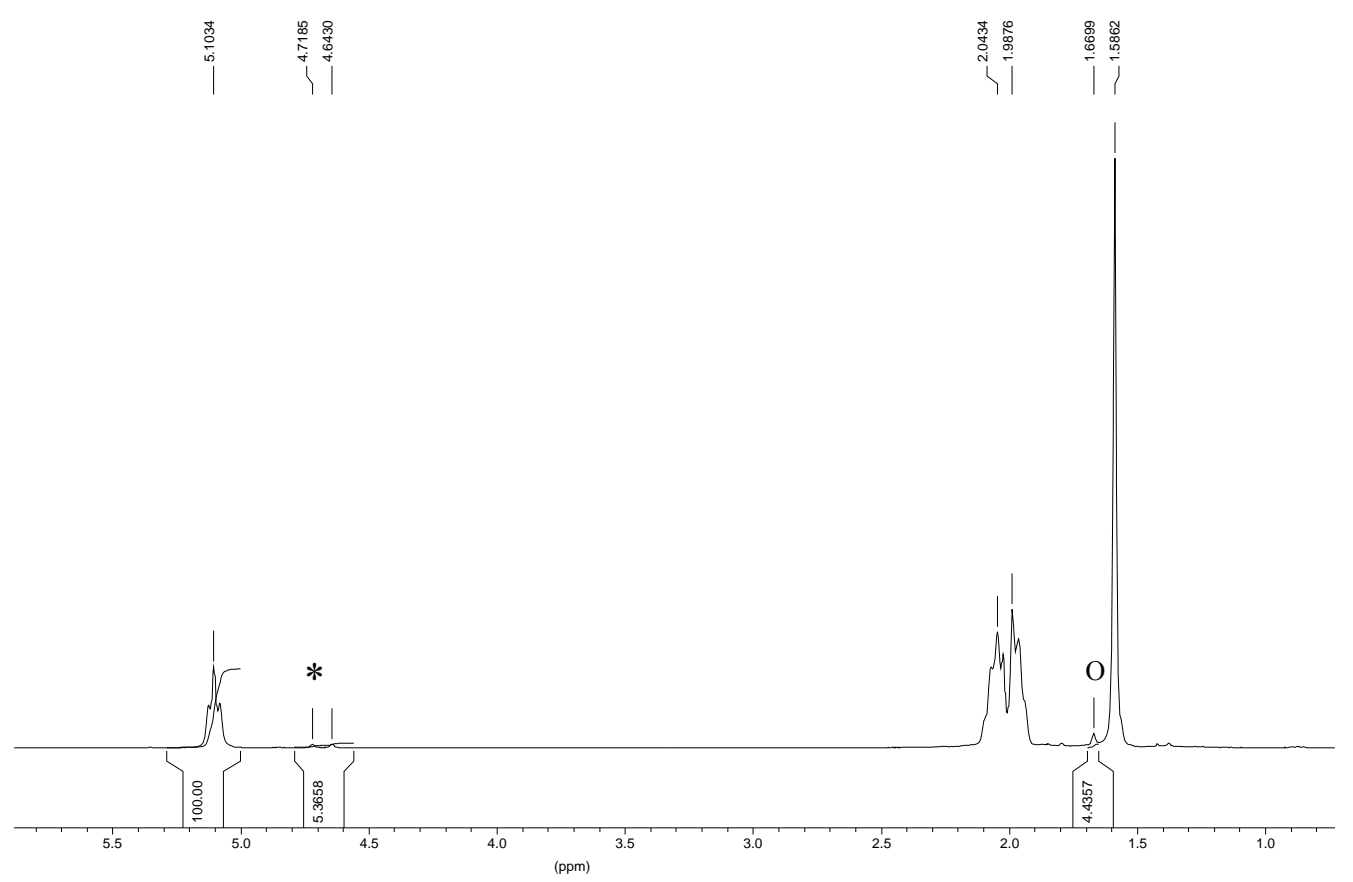

Figure 4 (a) 


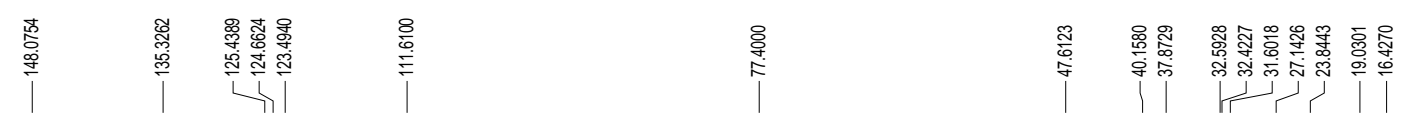

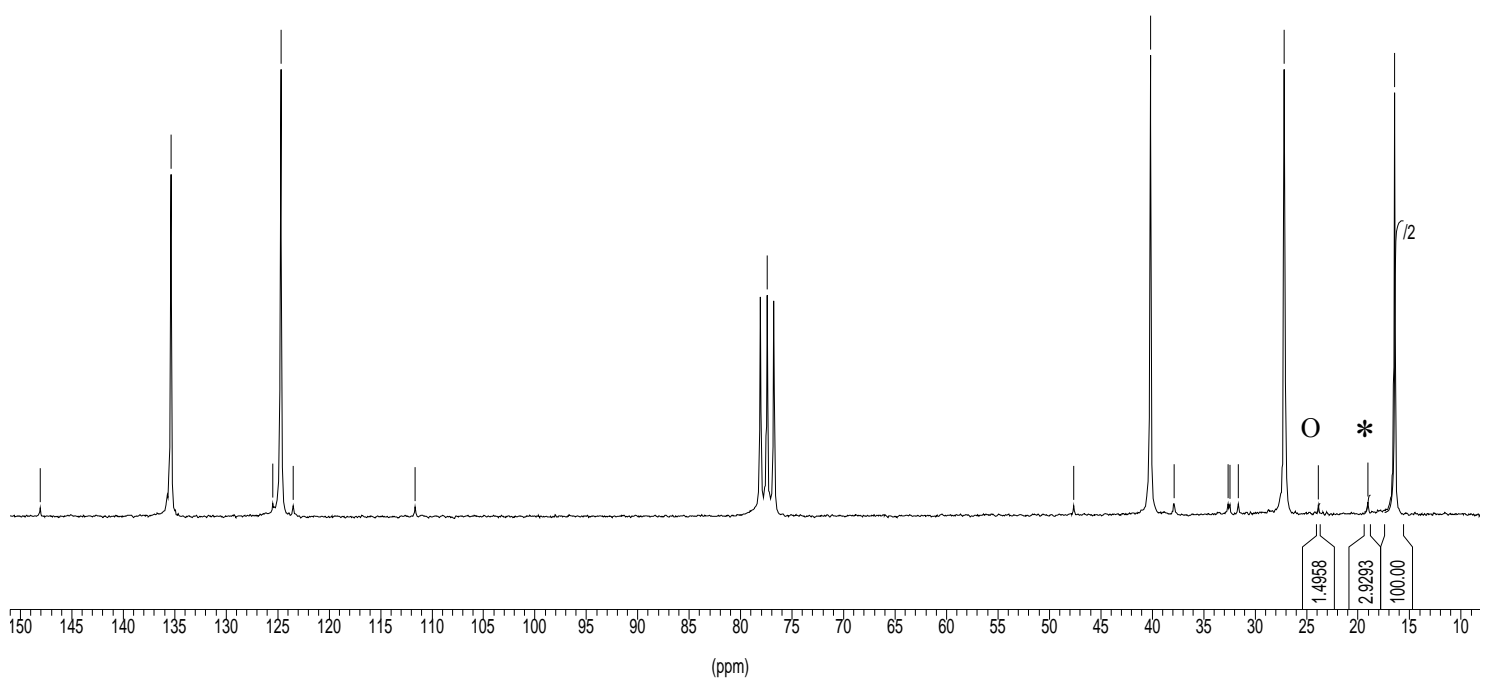

Figure 4 (b) 
Table 1. Isoprene polymerisation with borohydrido half-neodymocene / BEM catalysts. $^{[\mathrm{a}]}$

\begin{tabular}{lllllll}
\hline run & Precatalyst & $\begin{array}{l}\text { Yield } \\
{[\%]}\end{array}$ & $\begin{array}{l}\text { Rate oftrans- } \\
\text { PI [\%] }]^{[b]}\end{array}$ & $\begin{array}{l}\overline{M_{n}} \\
(\mathrm{exp})^{[\mathrm{c}]}\end{array}$ & PDI $^{[\mathrm{d}]}$ & $\overline{M_{n}}$ (calc. $^{[\mathrm{e}]}$ \\
\hline 1 & $\mathbf{1 a}$ & 84 & 98.2 & 58200 & 1.16 & 56000 \\
2 & $\mathbf{2 a}^{[\mathrm{f}]}$ & 41 & 95.2 & 31600 & 1.57 & 28000 \\
3 & 3a & 59 & 96.2 & 35500 & 1.32 & 37300 \\
4 & $\left(\mathrm{C}_{5} \mathrm{Me}_{5}\right) \mathrm{Nd}\left(\mathrm{BH}_{4}\right)_{2}(\mathrm{THF})_{2}$ & 80 & 97.4 & 52300 & 1.18 & 53700
\end{tabular}

[a] Conditions: $10 \mu \mathrm{mol} \mathrm{Nd}, 1 \mathrm{~mL}$ toluene, $[\mathrm{BEM}] /[\mathrm{Nd}]=1$, [isoprene]/[Nd] $=1000, \mathrm{~T}$ $=50{ }^{\circ} \mathrm{C}, \mathrm{t}=2 \mathrm{~h}$. [b] Determined by both ${ }^{1} \mathrm{H}$ and ${ }^{13} \mathrm{C}$ NMR integrations (average variation observed \pm 0.2 on the value of the percentage for several measurements of the same sample), see ref. 32. [c] Determined by Steric Exclusion Chromatography calibrated with PS standards. [d] PDI $=\overline{M_{w}} / \overline{M_{n}}$. [e] yield * [isoprene]/[Nd]. [f] t $=6 \mathrm{~h}$. 